ISSN = 1980-993X - doi:10.4136/1980-993X
www.agro.unitau.br/ambi-agua
E-mail: ambi-agua@agro.unitau.br
Tel.: (12) 3625-4116

\title{
Progress of Ambiente \& Agua Journal after three years of life
}

\author{
(doi:10.4136/ambi-agua.81)
}

\section{Getulio Teixeira Batista}

\begin{abstract}
Professor at the Master Degree Program in Environmental Sciences of the University of Taubaté Estrada Municipal Dr. José Luiz Cembranelli, 5.000; Bairro Itaim; 12.081-010 - Taubaté, SP E-mail: ambi-agua@agro.unitau.br
\end{abstract}

\begin{abstract}
After completing three years since its first issue was published on August 2006, we are proud to report the development of Ambiente \& Agua - An Interdisciplinary Journal of Applied Science, ISSN:1980-993X, doi:10.4136/1980-993X that is publishing its $10^{\text {th }}$ issue with 17 peer reviewed articles. Thanks to the great support of the scientific community, especially to the authors and peer reviewers, all issues have been published on-time, i.e. at the end of April, August and December. Missions and goals are progressively being achieved. We have two new metadata harvester agencies listing the journal: the Portal of the Brazilian Agency from the Ministry of Education concerned with the graduate level education, known as CAPES in its service "Portal de Periódicos da CAPES" accessed by most of the scientific community in Brazil and the Summary of Brazilian Journals (Sumarios.org). We report in this current issue the growing international interest in the journal, by monitoring the access of readers, using several tools. Therefore, we anticipate a growing interest in the journal from not only the Brazilian but also from the global scientific community.
\end{abstract}

Keywords: Ambi-Agua; Portal CAPES; Sumarios.org; Google Analytics; ClusterMaps, Geovisite; Environment and Water.

\section{INTRODUCTION}

Most Ambi-Agua editorials highlight new developments achieved by the journal. In this issue we emphasize new indexing and the number and geographical location of readers. We attribute the growing interest in this journal to the "golden open access" policy and the continuous search for quality standard based on a large, highly qualified peer review panel, in addition to a strong call for paper submission policy. The open access continues to be powered by the OAI-PMH communication protocol (Batista, 2007). Figure 1 shows the countries that have frequently accessed Ambi-Agua since we begin monitoring accesses (Google Analytics, 2009).

Table 1 shows the number of visits from countries where Ambi-Agua has been more frequently accessed since we started monitoring access in 2007. A total of 45,676 visits with an average of 3.17 pages per visit and an average time of 2:05 minutes per visit, registered from September 15, 2007 up to August 25, 2009. Data from March 01, 2008 till April 29, 2008 were not processed.

Figure 2 shows the distribution and concentration of visitors since we begun to monitor access using ClustrMaps ${ }^{\circledR}$ up to August 5, 2009. The advantage of using this monitoring system is the possibility of users checking in a daily basis the frequency and location of visitors. 
BATISTA, G. T. Progress of Ambiente \& Agua Journal after three years of life. Ambi-Agua, Taubaté, v. 4, n. 2, p. 4-9, 2009. (doi:10.4136/ambi-agua.81)

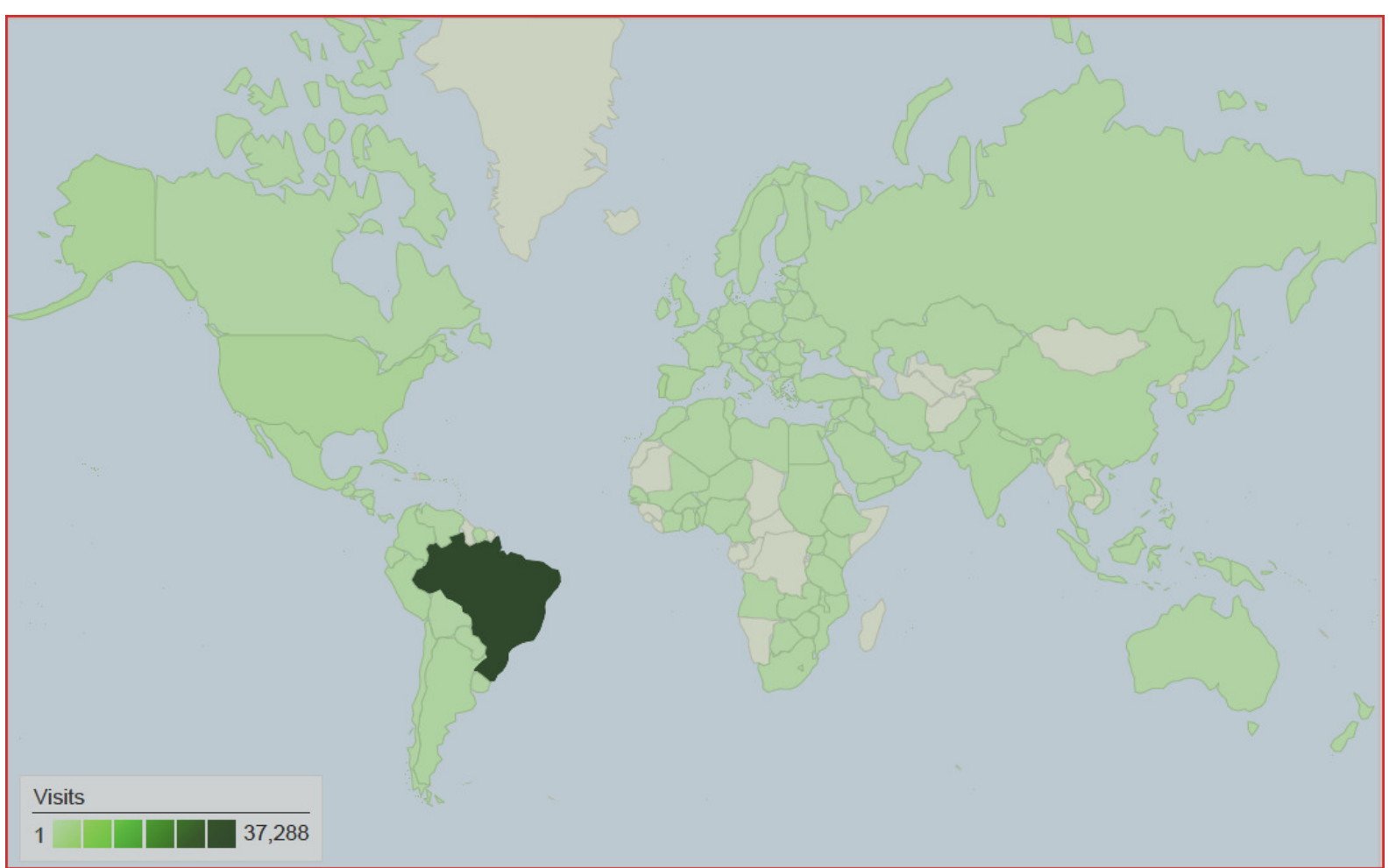

Figure 1. Countries from where Ambi-Agua has been accessed in a period of September 15, 2007 August 25, 2009. Total of 45,676 visits from 138 countries/territories. Source: Google Analytics (2009).

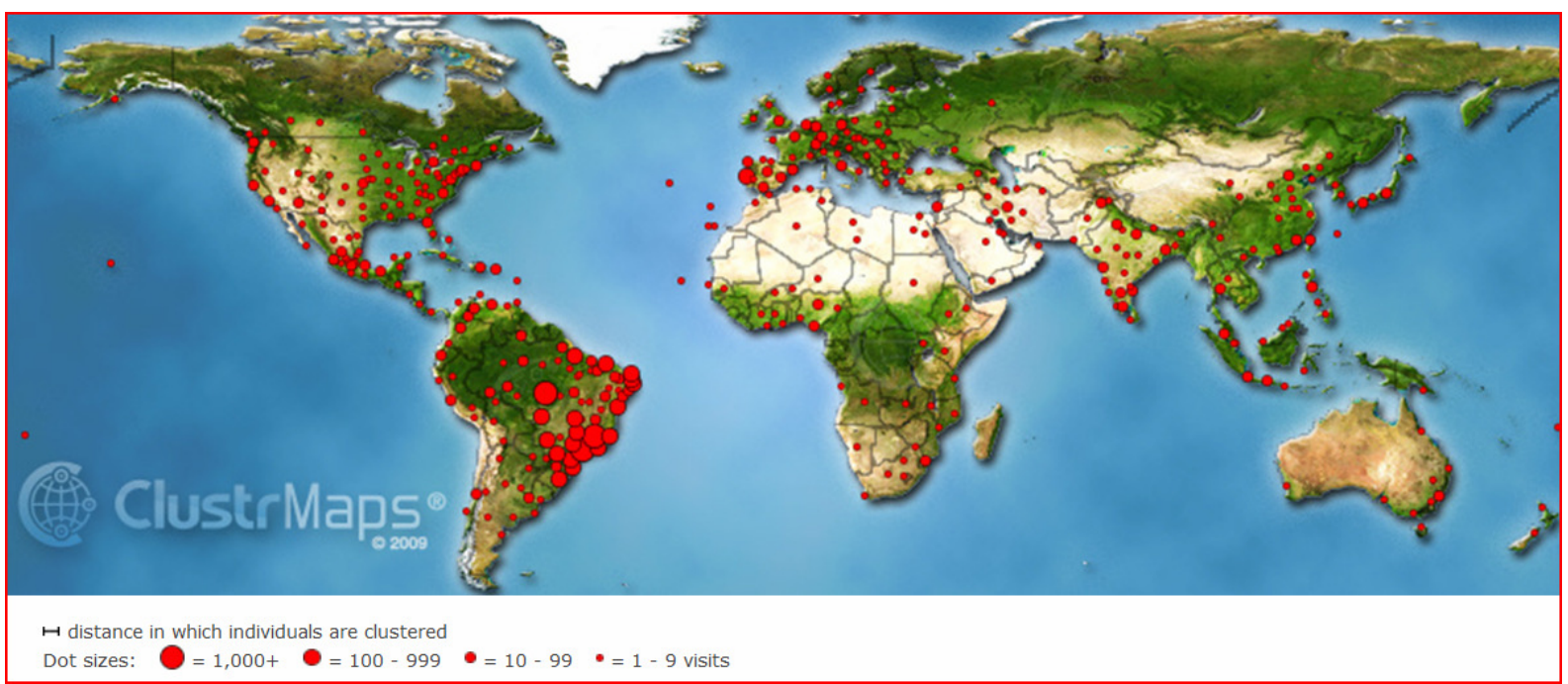

Figure 2. Location of Ambi-Agua visitors based on ClustrMaps ${ }^{\circledR}$ from December 8, 2008 to August 5, 2009). Source: ClustrMaps (2009). 
BATISTA, G. T. Progress of Ambiente \& Agua Journal after three years of life. Ambi-Agua, Taubaté, v. 4, n. 2 , p. 4-9, 2009. (doi:10.4136/ambi-agua.81)

Table 1. Frequency of access from countries where Ambi-Agua has been mostly accessed ( $\geq 10$ visits) in the period between September 15, 2007 and August 25, 2009.

\begin{tabular}{|c|c|c|c|}
\hline Country/Territory & Visits & Pages/Visit & $\begin{array}{c}\text { Average Time on Site } \\
\text { (seconds) }\end{array}$ \\
\hline Brazil & 15199 & 3.77 & 149.0 \\
\hline United States & 468 & 3.90 & 190.3 \\
\hline Portugal & 420 & 2.23 & 55.7 \\
\hline India & 322 & 2.80 & 148.4 \\
\hline Mexico & 277 & 2.96 & 154.7 \\
\hline Spain & 149 & 2.98 & 111.5 \\
\hline Japan & 143 & 8.28 & 250.9 \\
\hline Colombia & 125 & 2.43 & 80.8 \\
\hline China & 112 & 2.55 & 66.5 \\
\hline Venezuela & 91 & 2.90 & 112.9 \\
\hline United Kingdom & 90 & 2.46 & 87.9 \\
\hline Peru & 85 & 4.92 & 168.2 \\
\hline Argentina & 79 & 5.05 & 211.1 \\
\hline Canada & 72 & 2.33 & 66.4 \\
\hline Germany & 65 & 2.78 & 103.9 \\
\hline Nigeria & 51 & 2.16 & 216.5 \\
\hline Mozambique & 49 & 1.96 & 93.4 \\
\hline Indonesia & 45 & 1.98 & 121.7 \\
\hline Iran & 40 & 2.10 & 57.7 \\
\hline Australia & 37 & 1.86 & 68.6 \\
\hline Malaysia & 35 & 1.80 & 156.4 \\
\hline Italy & 35 & 1.71 & 95.9 \\
\hline France & 33 & 2.33 & 74.0 \\
\hline Yemen & 33 & 7.09 & 472.0 \\
\hline Philippines & 31 & 1.81 & 63.5 \\
\hline Chile & 27 & 3.74 & 164.2 \\
\hline Thailand & 21 & 1.33 & 16.0 \\
\hline Ecuador & 21 & 1.67 & 73.6 \\
\hline Netherlands & 20 & 2.40 & 70.3 \\
\hline South Africa & 18 & 1.28 & 78.8 \\
\hline Dominican Republic & 18 & 4.78 & 277.7 \\
\hline Turkey & 17 & 1.35 & 20.6 \\
\hline Pakistan & 16 & 1.44 & 39.2 \\
\hline Angola & 16 & 1.81 & 158.2 \\
\hline Israel & 15 & 1.80 & 68.3 \\
\hline Egypt & 15 & 3.00 & 189.9 \\
\hline Kenya & 15 & 2.07 & 292.1 \\
\hline South Korea & 15 & 1.53 & 19.9 \\
\hline Sweden & 15 & 2.00 & 62.5 \\
\hline Taiwan & 14 & 1.86 & 14.5 \\
\hline Puerto Rico & 13 & 1.46 & 19.2 \\
\hline Paraguay & 11 & 4.82 & 175.5 \\
\hline Saudi Arabia & 11 & 2.09 & 29.5 \\
\hline Morocco & 11 & 1.91 & 12.5 \\
\hline Cuba & 10 & 1.10 & 8.4 \\
\hline Panama & 10 & 5.20 & 250.0 \\
\hline Belgium & 10 & 1.40 & 16.7 \\
\hline Bolivia & 10 & 2.00 & 74.7 \\
\hline Costa Rica & 10 & 2.60 & 51.1 \\
\hline
\end{tabular}


Additionally, we installed a real time monitoring of Ambi-Agua visitors using the Geovisite (2009). Any time people are logged in they can see the location of other visitors. An example of one of those maps can be seen in Figure 3 for one specific day.

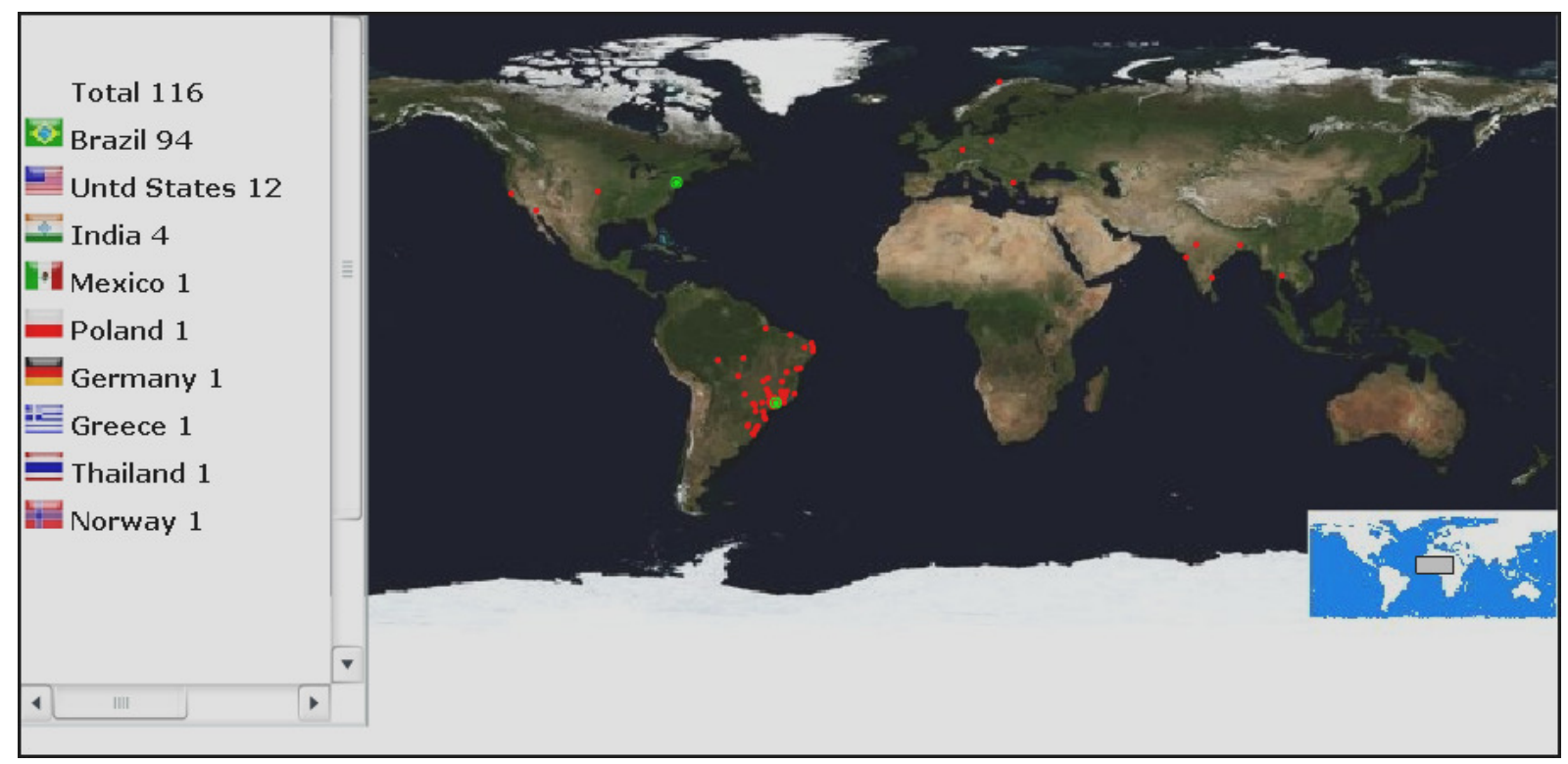

Figure 3. Example (August 27, 2009) of a map showing the real time (green) and daily location (red) of visitors based on Geovisite (2009).

It can be observed that visits are originated from different countries and regions. We are monitoring access of each individual article and will report on this in the future. It is worth mentioning that these reported accesses were only to the journal site, but articles can be downloaded from other servers. They can be consulted directly in Socolar (http://www.socolar.com/vn.aspx?id=6545); Redalyc (http://redalyc.uaemex.mx/redalyc/src/ inicio/HomRevRed.jsp?iCveEntRev=928); and Sumários.org (http://www.sumarios.org/ revista.asp?id_revista $=315$ ).

Table 2 lists the current data harvesters that index Ambiente \& Agua. New indexers include Sumários.org that is concerned with scientific Brazilian journals and has been launched in 2007 to foster the visibility of the scientific production and it is run by the Ribeirão Preto Scientific Research Foundation (FUNPEC-RP). It currently has in its server all abstracts published by Ambi-Agua and shortly will have fully text available. The second indexer, the "Portal de Periódicos da CAPES" (Brasil, 2009) lists national and international journals in all thematic areas and includes open access journals that were recommended by QUALIS CAPES (Batista, 2009) and is considered a very important source of information for the Academia in Brazil. The third indexer that lists Ambiente \& Agua is the Environment Complete $^{\mathrm{TM}}$ by Ebsco Publishing that covers several science themes related to the environment. 
BATISTA, G. T. Progress of Ambiente \& Agua Journal after three years of life. Ambi-Agua, Taubaté, v. 4, n. 2 , p. 4-9, 2009. (doi:10.4136/ambi-agua.81)

Table 2. Directories that list the journal Ambi-Agua as of August of 2009.

\begin{tabular}{|c|c|}
\hline$O O A$ & $\begin{array}{l}\text { OAIster: The University of Illinois OAI-PMH Data } \\
\text { Provider Registry: } \\
\text { (http://gita.grainger.uiuc.edu/registry/details.asp?id=2190) }\end{array}$ \\
\hline & $\begin{array}{l}\text { Open Journal Systems: } \\
\text { http://www.openarchives.org/Register/ ListFriends } \\
\text { http://www.agro.unitau.br/seer/index.php/index/oai }\end{array}$ \\
\hline $\begin{array}{l}\text { GE PROJECT } \\
\text { ives Harvester }\end{array}$ & $\begin{array}{l}\text { The Public Knowledge Project is a federally funded } \\
\text { research initiative at the University of British Columbia } \\
\text { and Simon Fraser University on the west coast of } \\
\text { Canada. } \\
\text { http://pkp.sfu.ca/harvester2/demo/index.php/browse/index/677 }\end{array}$ \\
\hline & http://livre.cnen.gov.br/ConsultaPorLetra.asp?Letra=A \\
\hline $\begin{array}{l}\text { DIRECTORY OF } \\
\text { OPEN ACCESS } \\
\text { JOURNALS }\end{array}$ & $\begin{array}{l}\text { http://www.doaj.org/openurl?genre=journal\&issn=1980 } \\
\text { 993X }\end{array}$ \\
\hline & http://www.latindex.unam.mx/revista.php?opcion=1 \\
\hline & $\begin{array}{l}\text { ÍNDICE DE REVISTAS LATINAMERICAS EM CIÊNCIA } \\
\text { http://dgb.unam.mx/periodica.html }\end{array}$ \\
\hline & http://www.socolar.com/vn.aspx?id=6545 \\
\hline & $\begin{array}{l}\text { http://redalyc.uaemex.mx/redalyc/src/inicio/HomRevRe } \\
\text { d.jsp?iCveEntRev=928 - "Indizada en la Red de } \\
\text { Revistas Científicas de América Latina y El Caribe, } \\
\text { España y Portugal (Redalyc: } \\
\text { http://redalyc.uaemex.mx/)" }\end{array}$ \\
\hline & http://www.swets.com/ \\
\hline$\bigcap_{\text {a marine and aquatic sciences } c}$ & http://www.ifremer.fr/avano/archives.htm \\
\hline irios.org & http://www.sumarios.org/revista.asp?id_revista=315 \\
\hline 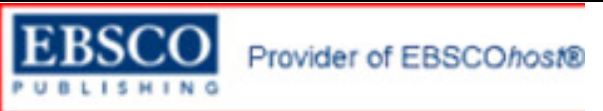 & $\begin{array}{l}\text { Environment Complete } \\
\text { http://www.ebscohost.com/titleLists/eih-coverage.htm }\end{array}$ \\
\hline cAPEs & $\begin{array}{l}\text { O Portal Brasileiro de Informação Científica } \\
\text { http://acessolivre.capes.gov.br/pesquisa.do?palavra=amb } \\
\text { iente\&letra=\&editor=\&assunto=\&tipo=All\&nac=0\&gra } \\
\text { tis=true }\end{array}$ \\
\hline
\end{tabular}




\section{FINAL REMARKS}

It has been demonstrated that Ambiente \& Agua is progressively achieving its goals and raising considerable interest from the scientific community. We know that it is time to start asking for funding from governmental agencies to support the operational procedures that currently depends heavily on voluntary work. We are grateful to our peer review panel members for their competent and timely job and to the authors that are submitting high quality manuscripts. We intend to improve our server and Internet link to have a more reliable service in the near future.

\section{REFERENCES}

BATISTA, G. T. Scientific Journal Indexing. Ambi-Agua, Taubaté, v. 2. n. 2, p. 3-6, 2007. Available: <http://www.agro.unitau.br/seer/index.php/ambi-agua/article/view/59/80>. Access: August, 2009. (doi:10.4136/ambi-agua.22)

BATISTA, G. T. New accomplishments of Ambiente \& Agua scientific journal. Ambi-Agua, Taubaté, v. 4, n. 1, p. 3-5, 2009. Available: http://www.agro.unitau.br/seer/index.php/ ambi-agua/article/view/221/301. Access: August, 2009. (doi:10.4136/ambi-agua.69)

BRASIL. Ministério da Educação. Cordenação de Aperfeiçoamento de Pessoal de Nível Superior. Portal Brasileiro de Informação Científica. 2009. Available: <http://acessolivre.capes.gov.br/>. Access: August, 2009.

GOOGLE ANALYTICS. Enterprise-class web analytics made smarter, friendlier and free. Available: <http://www.google.com/analytics/>. Access: August, 2009.

CLUSTRMAPS. ClustrMaps Geolocation Hit Counter. <http://www.clustrmaps.com/>. Access: August, 2009.

GEOVISITE. Geo-localization, tracking and mapping procedure of internet users geographic location. Available: <http://www.geovisite.com/en/>. Access: August, 2009. 